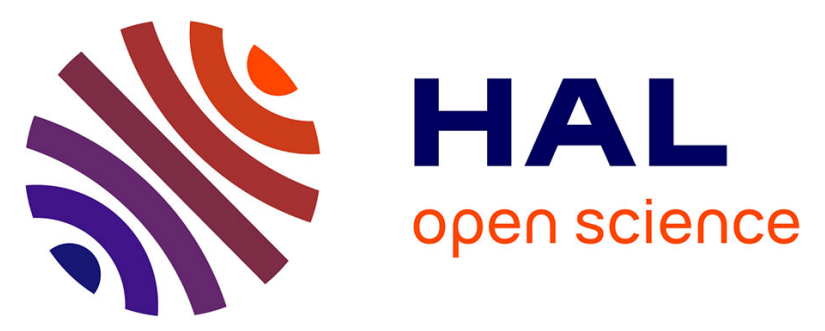

\title{
Pyrazol(in)e derivatives of curcumin analogs as a new class of anti- Trypanosoma cruzi agents
}

\author{
Dimitris Matiadis, Tatiana Saporiti, Elena Aguilera, Xavier Robert, \\ Christophe Guillon, Nallely Cabrera, Ruy Pérez-Montfort, Marina Sagnou, \\ Guzmán Alvarez
}

\section{To cite this version:}

Dimitris Matiadis, Tatiana Saporiti, Elena Aguilera, Xavier Robert, Christophe Guillon, et al.. Pyrazol(in)e derivatives of curcumin analogs as a new class of anti- Trypanosoma cruzi agents. Future Medicinal Chemistry, 2021, 13 (8), pp.701-714. 10.4155/fmc-2020-0349 . hal-03230237

\section{HAL Id: hal-03230237 https://hal.science/hal-03230237}

Submitted on 9 Jun 2021

HAL is a multi-disciplinary open access archive for the deposit and dissemination of scientific research documents, whether they are published or not. The documents may come from teaching and research institutions in France or abroad, or from public or private research centers.
L'archive ouverte pluridisciplinaire HAL, est destinée au dépôt et à la diffusion de documents scientifiques de niveau recherche, publiés ou non, émanant des établissements d'enseignement et de recherche français ou étrangers, des laboratoires publics ou privés. 
Submitted version of the article, published in 2021 (Future Medicinal Chemistry 2021 13:8, 701-714 https://www.future-science.com/doi/10.4155/fmc-2020-0349 )

\title{
Pyrazol(in)e derivatives of curcumin analogs as a new class of anti- Trypanosoma cruzi agents
}

Dimitris Matiadis ${ }^{1}$, Tatiana Saporiti ${ }^{2}$, Elena Aguilera ${ }^{3}$, Xavier Robert ${ }^{4}$, Christophe Guillon $^{4}$, Nallely Cabrera ${ }^{5}$, Ruy Pérez-Montfort ${ }^{5}$, Marina Sagnou ${ }^{1}$, Guzman Alvarez ${ }^{2}$

${ }^{1}$ National Center for Scientific Research “Demokritos”, Institute of Biosciences \& Applications, 15310 Athens, Greece

${ }^{2}$ Laboratorio de Moléculas Bioactivas, Universidad de la República, CENUR Litoral Norte, 60000 Paysandú, Uruguay

3 Grupo de Química Medicinal-Laboratorio de Química Orgánica, Facultad de Ciencias, Universidad de la República, Montevideo, C.P. 11400, Uruguay; elepao168@gmail.com(E.A.)

4 Equipe Rétrovirus et Biochimie Structurale, Université de Lyon, CNRS, MMSB, Lyon, France.

5 Departamento de Bioquímica y Biología Estructural, Instituto de Fisiología Celular, Universidad Nacional Autónoma de México, Ciudad de México, C.P. 04510, Mexico; ncabrera@ifc.unam.mx (N.C.); ruy@ifc.unam.mx (R.P.-M.)

\begin{abstract}
Aim: In this work, we report the synthesis and biological evaluation of a small library of fifteen functionalized 3-styryl-2-pyrazolines and pyrazoles, derived from monocarbonyl and dicarbonyl curcuminoids, respectively, as antitrypanosomal agents. Methods \& results: The products were prepared via the cyclization reaction between the corresponding curcuminoids and the appropriate hydrazines. All of the derivatives synthesized were investigated for their antitrypanosomal activities. Compounds $\mathbf{4 a}$ and $\mathbf{4 e}$ showed significant activity against epimastigotes of Trypanosoma cruzi with $\mathrm{IC}_{50}$ values of 5.0 and $4.2 \mu \mathrm{M}$ respectively accompanied by no toxicity to mammalian non-cancerous cells, whereas compound $\mathbf{6 a}$ was found to effectively inhibit $T$. cruzi triosephosphate isomerase. Conclusion: The 16-fold (for 4a) and 6-fold (for $\mathbf{4 e}$ ) higher potencies of these derivatives in comparison to their curcuminoid precursors, make them an attractive and promising new family of $T$. cruzi inhibitors.
\end{abstract}




\section{Keywords}

pyrazolines; 4,5-dihydropyrazoles; antitrypanosomal agents; Chagas disease;

Trypanosoma cruzi

\section{Introduction}

Chagas disease, also known as American trypanosomiasis, is a potentially life-threatening illness caused by the parasite Trypanosoma cruzi. More than six million people, mostly in Latin America are estimated to be infected by $T$. cruzi [1]. The only available drugs for its treatment are benznidazole and nifurtimox (Fig. 1). However, both medicines are far from ideal. In the benznidazole case, adverse reactions occur in up to $40 \%$ of treated adult patients, while the treatment is only for a short duration and carried out once [2]. The other medication, nifurtimox, is the only one available in some countries, including the United States of America. It produces, in general, frequent, but mild side effects, however, special attention should be paid to potentially severe symptoms like depression, rash, and anxiety [3]. It is also contraindicated for people with a background of neurological or psychiatric disorders [1]. Given these facts, there is an urgent need for new efficient, and safer drugs [4].

Curcumin or diferoylmethane, the most abundant bioactive natural product extracted from roots of Curcuma longa has been reported as an effective agent for the treatment of T. cruzi infections [5]. More specifically, curcumin was the most active typanocidal agent among the major constituents of $C$. longa, with $\mathrm{IC}_{50}$ value of $10.13 \mu \mathrm{M}$ on epimastigotes compared to demethoxycurcumin and bisdemethoxycurcumin which exhibited $\mathrm{IC}_{50}$ values of 11.07 and $45.33 \mu \mathrm{M}$, respectively. Moreover, being a natural product low systemic toxicity was observed. Finally, in vivo studies on $T$. cruzi-infected mice revealed a significant reduction in parasitemia and tissue parasite load, increased survival rate and improved pathological conditions [6]. Therefore, curcumin can serve as a promising lead compound for the treatment of Chagas disease. However, it suffers from poor bioavailability, chemical instability and fast systemic elimination [7].

Monocarbonyl analogs of curcumin (MACs) represent a highly attractive and in some cases a highly promising categoryof curcumin synthetic analogs. In many cases, they demonstrate higher potency than the diketo-curcuminoid counterparts, being at the same time easier to produce and more stable [8]. Alvarez et al. have reported the synthesis and antitrypanosomal evaluation of cyclohexanone, cyclopentanone, cycloheptanone 
curcuminoids bearing thiophene, furan and unsubstituted phenyl rings with $\mathrm{IC}_{50}$ values against epimastigotes of $T$. cruzi lower than $5 \mu \mathrm{M}$. Those compounds were potent and selective inhibitors of triosephosphate isomerase of $T$. cruzi. This enzyme is a promising drug target in Chagas disease [9,10]. More recently, Din et al. synthesized thirty-four symmetrical and unsymmetrical cyclohexanone-based curcuminoids bearing substituted phenyl rings as antiparasitic compounds. They found that two unsymmetrical molecules with methoxy substitutions on the phenyl rings were the most potent compounds against epimastigotes of $T$. cruzi ( $\mathrm{IC}_{50}$ values of 5.2 and $3.0 \mu \mathrm{M}$, respectively) displaying at the same time low cytotoxicity against Vero cells [11].

On the other hand, 2-pyrazolines, five-membered heterocycles usually derived from chalcones or monocarbonyl curcuminoids, are versatile molecules with prominent pharmacological profile [12-14], which includes anticancer [15-17], anti-inflammatory [18,19], antiviral [20] and antidepressant activities [21]. The reports on antitrypanosomal activities of pyrazoline derivatives are scarce, and not all of them demonstrate active products [22,23]. Cohen et al. have published the synthesis and biological evaluation of more than one hundred thiosemicarbazone derivatives as inhibitors of the trypanosomal cysteine protease cruzipain. Among them, a few thiocarboxamide pyrazolines (Fig. 1) were identified as highly potent with $\mathrm{IC}_{50}$ values in the nanomolar range [24]. In two recent publications, Insuasty et al. reported the synthesis and antitrypanosomal activity of novel caffeine-based pyrazolines [25] and thiazolyl-pyrazoline derivatives bearing nitrogen mustard (Fig. 1) [26]. 
<smiles>O=C(Cn1ccnc1[N+](=O)[O-])NCc1ccccc1</smiles>

Benznidazole

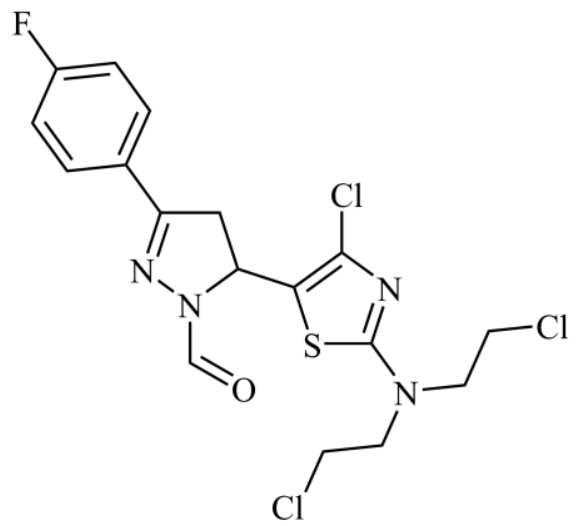

$N$-Formyl thiazolyl-pyrazoline

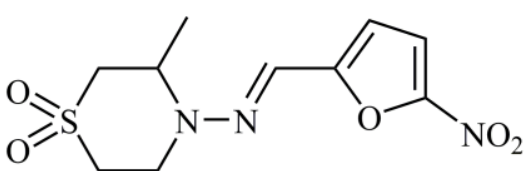

Nifurtimox<smiles>CC1CN(C(N)=S)N=C1c1cccc(C(F)(F)F)c1</smiles>

Thiocarboxamide pyrazoline

Fig 1. Heterocyclic antitrypanosomal agents.

All the aforementioned evidence promted us to design and synthesize substituted pyrazole/2-pyrazolines generated from curcuminoid precursors aiming to combine these two bioactive structures into one molecule, thus further improving the promising activities of curcuminoids. Herein, we report the synthesis of a small library of this class of pyrazole/pyrazolines to perform: a) an initial in vitro screening against the epimastigote form of T. cruzi, b) investigation of triosephosphate isomerase (TcTIM) inhibition and c) evaluation of toxicity in mammalian cells.

\section{Results and Discussion}

\section{Chemistry}

The thirteen pyrazoline derivatives $(\mathbf{1}$ - 5) were prepared from the corresponding cyclohexanone-based (1a-e) or acetone-based (1f,g) monocarbonyl precursors. The compounds can be grouped as $N$-pyridine pyrazolines $\mathbf{2 a , b}, N$ - $p$-fluorophenyl pyrazolines 3a-c, unsubstituted (NH) pyrazolines $4 \mathbf{a}-\mathbf{e}$ and $N$-benzoic or $N$-benzoate pyrazolines 5 a-c. All products were prepared from inexpensive starting materials, in moderate to high yields, 
in high purity as evidenced by elemental analysis and NMR, without the need of any chromatographic method for purification.

Pyrazolines 2a,b were synthesized using 2-hydrazinopyridine in neat ethanol under reflux for three days. In particular, the synthesis and characterization of $\mathbf{2 a}$ has been reported previously [27]. Fluorophenyl derivatives 3a-c were prepared using hydrochloric 4fluorophenyl hydrazine in the presence of sodium ethoxide in ethanol.

The synthesis of unsubstituted pyrazolines 4a-e proved a challenging task, due to instability and decomposition of the products when dissolved in most organic solvents. This behavior was not unexpected, since it has been documented in the literature [28-31]. The two main obstacles we had to overcome in order to obtain a high purity product were: a) the autoxidation of the products upon exposure to the atmosphere [28,31] and b) the fact that they cannot be purified by chromatographic methods $[29,30]$. Therefore, the reaction, handling of the mixture and any work-up were done strictly under nitrogen atmosphere to avoid the exposure to oxygen. Moreover, when precipitate was formed at the end of the reaction period, as in the cases of $\mathbf{4 a , b}, \mathbf{e}$ this had to be collected only within a few hours after the end of the reaction. Failing to do so, resulted in the formation of a mixture of at least two inseparable products. In the case of products that did not precipitate spontaneously, as in compounds $\mathbf{4 c}, \mathbf{d}$, a few drops of water were added in the solution after completion of the reaction. 


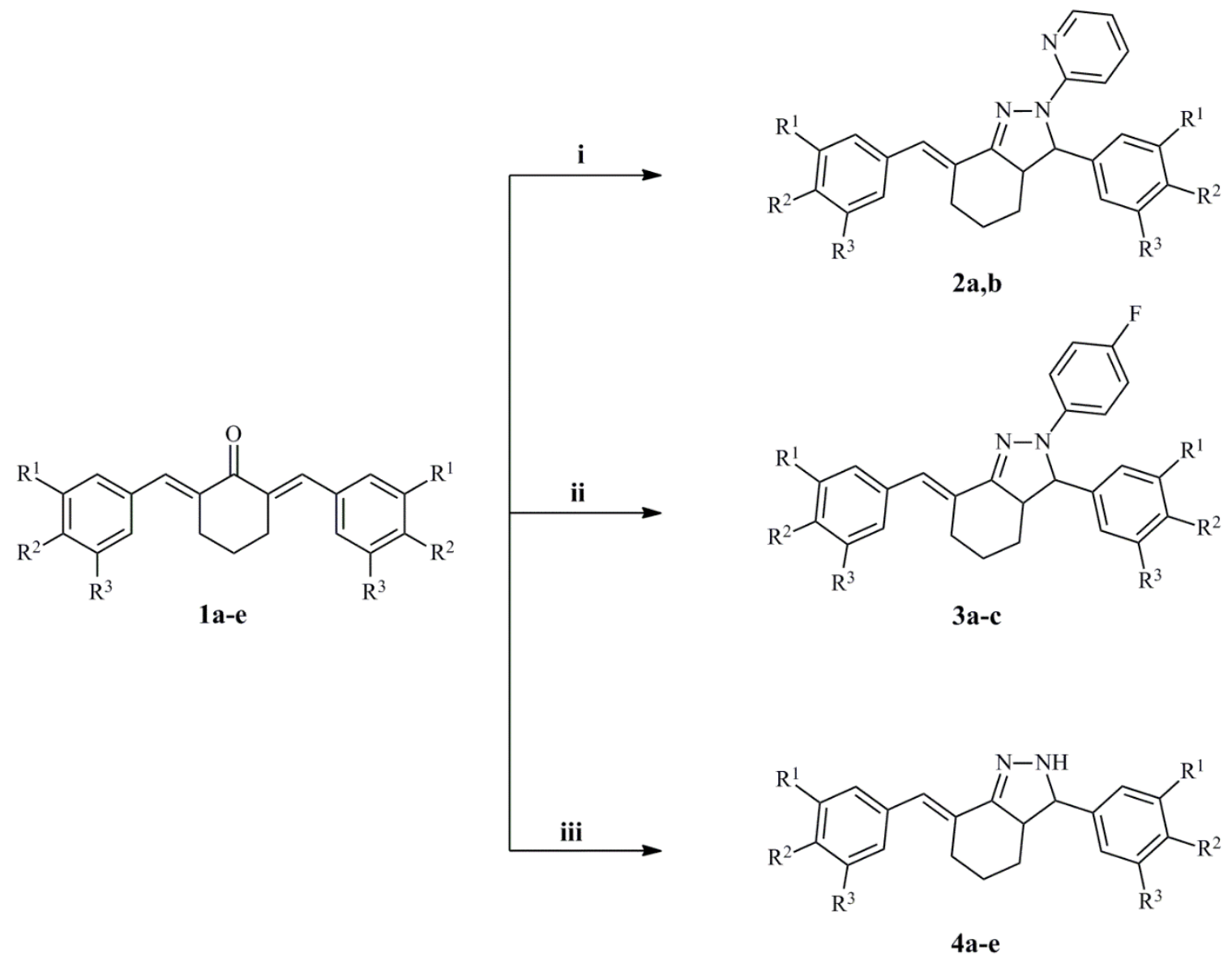

Scheme 1. Synthesis of pyrazolines $\mathbf{2 a}, \mathbf{b}, \mathbf{3 a - c}$ and 4a-e from cyclohexanone monocarbonyl curcuminoids 1a-e. Reagents and conditions: i) 1a,b, 2-hydrazinopyridine, ethanol, 3 days, reflux; ii) 1a-c, 4-fluorophenyl hydrazine hydrochloride, NaOEt, EtOH, r.t. to reflux, 24 h, iii) 1a-e, hydrazine hydrate, EtOH, reflux, $1 \mathrm{~h}$

Compounds 5a-c were synthesized in glacial acetic acid under heating and their preparations have been recently reported along with full characterization and X-ray crystallographic analysis of $\mathbf{5 b}[32,33]$.<smiles>[R]c1cc(/C=C/C(=O)/C=C/c2cc([R])c([R])c([R])c2)cc([R])c1[R]</smiles><smiles>CC(C)(C)C</smiles><smiles>[R]C(=O)c1ccc(N2N=C(/C=C/c3cc([R])c([R])c([R])c3)CC2c2cc([R])c([R])c([R])c2)cc1</smiles> 
Scheme 2. Synthesis of pyrazolines 5a-c from monocarbonyl curcuminoids 1f,g. Reagents and conditions: i) 1f,g, 4-hydrazinobenzoic acid (for 5a,b) or ethyl 4-hydrazinobenzoate (for 5c), glacial acetic acid, $100{ }^{\circ} \mathrm{C}, 5 \mathrm{~h}$.

Pyrazoles 6a,b were synthesized according to literature procedures [34,35], slightly modified. These compounds were anticipated to provide an insight as to whether the activity might be affected by the presence of the pyrazole rather than the pyrazoline moiety in the molecule.

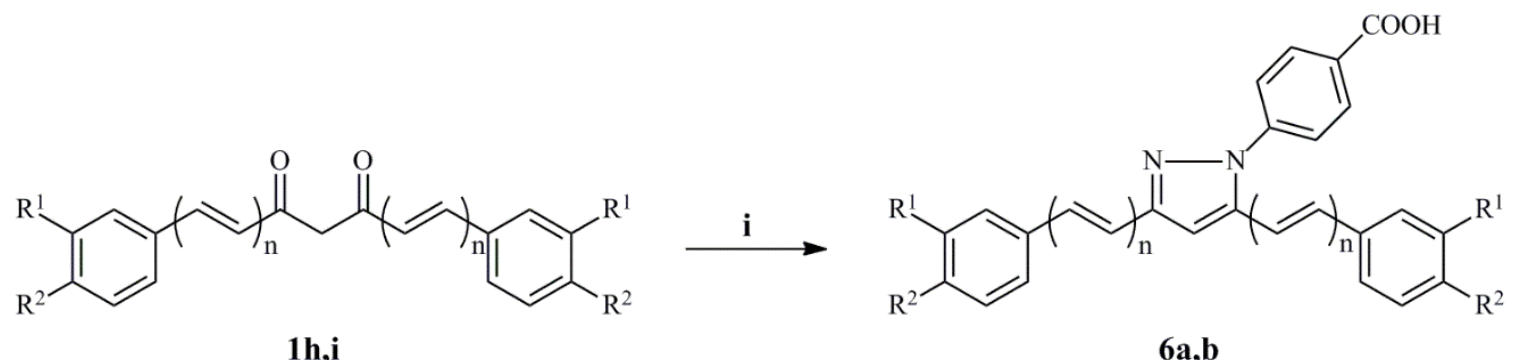

Scheme 3. Synthesis of pyrazoles $\mathbf{6 a}, \mathbf{b}$ from dicarbonyl curcuminoids $\mathbf{1} \mathbf{i}, \mathbf{j}$. Reagents and conditions: i) 1h,i, 4-hydrazinobenzoic acid, glacial acetic acid, Et ${ }_{3} \mathrm{~N}$, reflux, $12 \mathrm{~h}$.

The novel compounds $\mathbf{2 b}, \mathbf{3 a - c}$ and $\mathbf{4} \mathbf{c}$ were fully characterized by means of ${ }^{1} \mathrm{H}$ and ${ }^{13} \mathrm{C}$ NMR and elemental analysis. The formation of the pyrazoline ring is mainly characterized by the appearance of a doublet signal (4.90 to $4.56 \mathrm{ppm}$ ) for the compounds $\mathbf{2 a , b}$ and 3a-c and a doublet of doublets (4.29 to $4.32 \mathrm{ppm}$ ) for the unsubstituted (NH) pyrazolines 4a-e or the pyrazolines 5a-c not bearing the cyclohexyl ring (5.49 to $5.61 \mathrm{ppm}$ ) corresponding to the adjacent to $\mathrm{N}-1$ methine. In addition to the other expected signals, the ${ }^{1} \mathrm{H} \mathrm{NMR}$ of the unsubstituted derivatives 4a-e showed a doublet $(J=5.0 \mathrm{~Hz})$ at $\delta 7.26$ to $7.34 \mathrm{ppm}$ assigned to the proton of the secondary nitrogen $(\mathrm{N}-1)$ of the ring.

\section{Biological evaluation}

\section{Trypanosomicidal activity}

It was hypothesized that a TIM dimer interface inhibitor would be a successful strategy to identify molecules with selective antiparasitic activity. Therefore, curcumin analogs have been previously described as a potent and selective inhibitor of TcTIM, but these analogs have metabolic stability problems and they are also considered as PAINS compounds as Michael acceptors [ref.]. The new derivatives described in the present work address these 
issues by the reaction of this Michael acceptor motif towards the formation of nitrogen heterocyclic analogues. Table 1 summarises the results on the biological evaluation of the fifteen heterocyclic compounds synthesized. Firstly, as a consequence of our initial hypothesis the inhibition potential of TcTIM was evaluated. Compound $\mathbf{6 b}$ was the only molecule which exhibited interesting TcTIM inhibitory activity with an $\mathrm{IC}_{50}$ value of $15 \mu \mathrm{M}$. It is also important to note that $\mathbf{6 b}$ has no inhibition effect at $100 \mu \mathrm{M}$ on the human enzyme (HsTIM), demonstrating a selectivity of this molecule for TcTIM.. However, this IC $_{50}$ value is almost twice the one obtained for curcumin. Moreover, $\mathbf{6} \mathbf{b}$ did not exhibit any significant activity against $T$. cruzi epimastigotes which indicates that the TcTIM inhibiton potential alone was not enough to evoke antitrypanosomal activity.

Regarding the Trypanosomicidal activity against epimastigotes of T.cruzi three of the tested pyrazol(in)es exhibited moderate to good anti-T. cruzi activity. More specifically, 4a and $4 \mathbf{e}$ were the most active of all, exhibiting $\mathrm{IC}_{50}$ values of 5 and $4.2 \mu \mathrm{M}$, respectively. It is worthnoting that these values are smaller than the $\mathrm{IC}_{50}$ value of the reference drug, Nifurtimox, which was at the range of $7 \mu \mathrm{M}$, whereas curcumin exhibited an $\mathrm{IC}_{50}$ value of 10 $\mu \mathrm{M}$. Therefore, compounds $\mathbf{4 a}$ and $\mathbf{4 e}$ are highly promising Trypanosomicidal scaffolds for further exploitation. They share the common feature of para-substitution of the phenyl ring and 2$\mathrm{NH}$-pyrazoline derivatisaton of the bis-arylidene skeleton. It seems that the nature of this substitution is not critical for this activity since $\mathbf{4 a}$ posseses a -OMe group whereas $\mathbf{4 e}$ is $p$-fluoro derivative. In the case of $\mathbf{4 b}$ reduced activity was observed resulting in a three times higher $\mathrm{IC}_{50}$ value. This activity drop might be related to the di-substituted motif of the aromatic moiety. Interstingly, the para-substituted active derivatives $4 \mathbf{a}$ and $4 \mathbf{e}$ were found to be much less active against murine macrophages. This additional feature of selectivity is highly desirable for a compound to be further exploited as a potential Trypanosomicidal agent.

Table 1. Inhibition of TcTIM, Trypanosomicidal activity against epimastigotes of Trypanosoma cruzi, cytotoxicity against murine cells, and selective index of compounds $\mathbf{2 a}$, b, 3a-c, 4a-e, 5a-c and $\mathbf{6 a}, \mathbf{b}$.

\section{Groups of compounds}




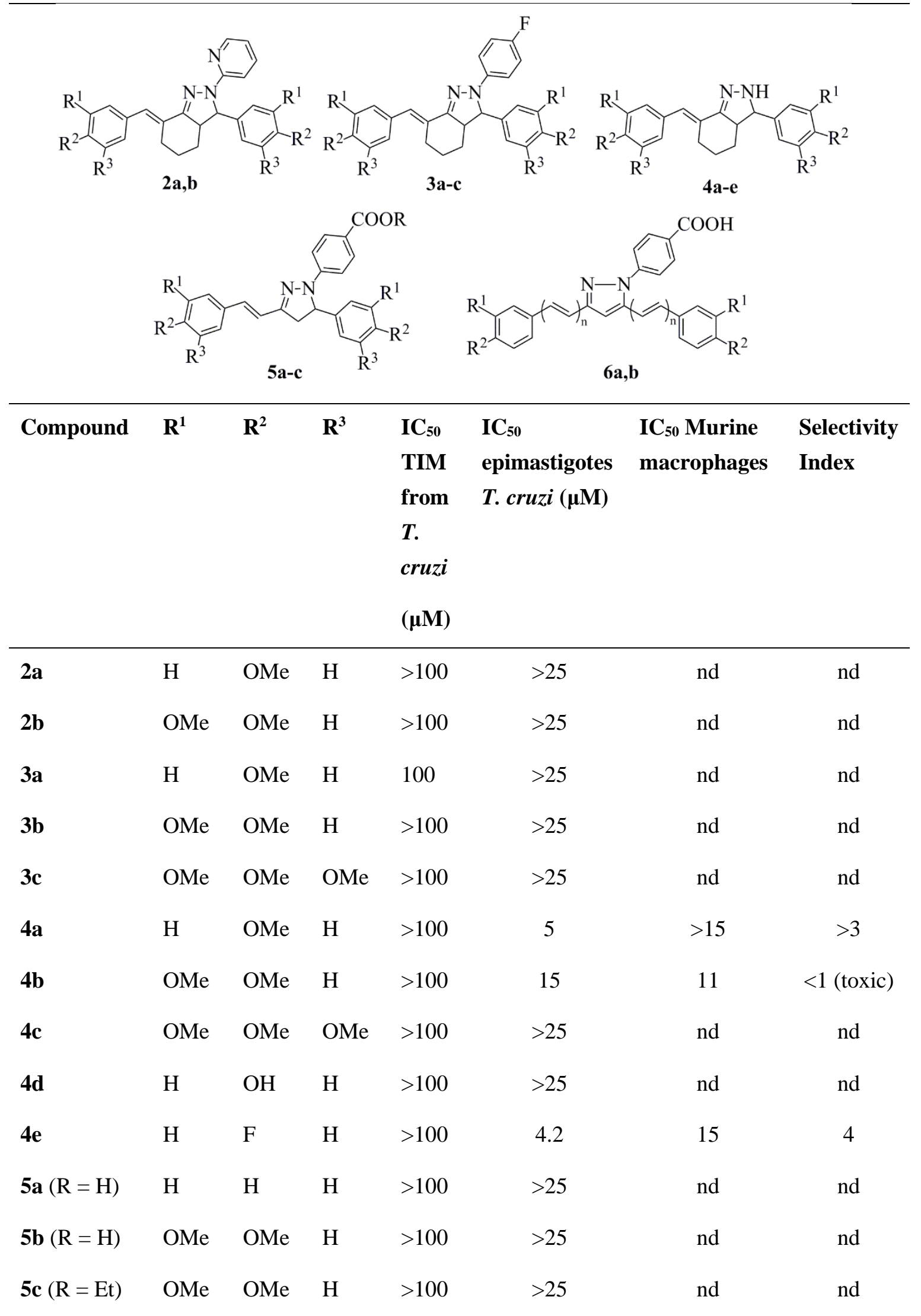




\begin{tabular}{lllllclc}
$\mathbf{6 a}(\mathbf{n = 1})$ & OMe & OMe & $\mathrm{H}$ & $>100$ & $>25$ & nd & nd \\
$\mathbf{6 b}(\mathbf{n}=\mathbf{2})$ & $\mathrm{H}$ & $\mathrm{H}$ & $\mathrm{H}$ & 15 & $>25$ & nd & nd \\
Curcumin & & & & 7 & 10 & 5 & $<1$ (toxic) \\
Nifurtimox & & & & $>100$ & 7 & $>100$ & $>15$ \\
\hline
\end{tabular}

Scheme 4A provides a rationalization of the results of this study compared to previous data on the parental arylideneketones [9]. The new analogs demonstrate better TcTIM activity and trypanosomicidal activity than the parental prototypes. More specifically, in the case of $\mathbf{6 b}$ resulting from the prototype I, the carboxyl moiety may potential interact with the protein which is essential for this enzymatic inhibition activity [9]. It is also worth mentioning that the pyrazole scaffold of $6 \mathbf{a}$ presents the highest degree of symmetry out of the fifteen molecules tested being in accordance with the notion that symmetry is essential for inhibition activity [10]. The inactivity against $T$. cruzi epimastigotes could be attributed to the presence of the ionizable carboxylic group, which may increase the difficulty of cell permeability, as it has been previously observed and reposted [36].

In the case of the new trypanosomicidal compounds $\mathbf{4 a}$ and $\mathbf{4 e}$, compound $\mathbf{4 e}$ was 6 times more potent than the prototype II (Scheme 4B). Compound 4a was 16 times more potent than the prototype III and both exhibited improved toxicology profile since they were much less toxic against murine macrophagies. The incorporation of a fluorophenyl or pyridine in the pyrazoline ring results in loss of activity. 


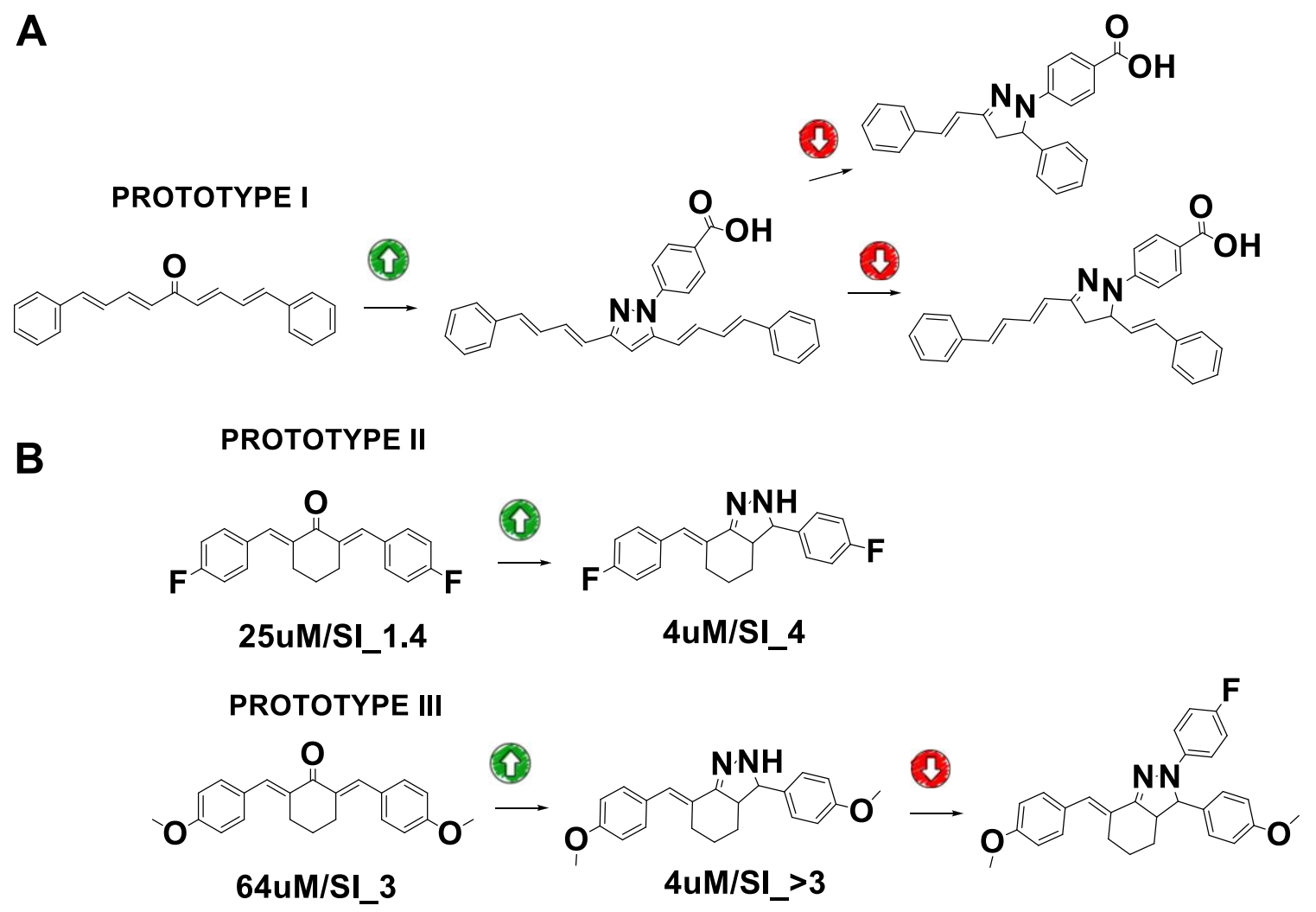

Scheme 4. A) Structure relationship in TcTIM activity and B) Structure relationship in epimastigote activity.

The predicted pharmacokinetic parameters and oral toxicity in rats are according to the drug-likeness. Also, the $\mathrm{LD}_{50}$ was higher than the reference drug Benznidazole and curcumin (Table 2).

Table 2. Predicted pharmacokinetic parameters and oral toxicity in vivo.

\begin{tabular}{|c|c|c|c|c|c|c|c|}
\hline Compound & $\begin{array}{c}\text { Solubility } \\
\text { (mg/mL) }\end{array}$ & $\begin{array}{c}\text { Gastrointestinal } \\
\text { Absorption }\end{array}$ & $\begin{array}{c}\text { Brain } \\
\text { Permeability }\end{array}$ & $\begin{array}{c}\text { CYP } \\
\text { inhibitor }\end{array}$ & $\begin{array}{c}\text { P-gp* } \\
\text { substrate }\end{array}$ & $\begin{array}{c}\text { Lipophilicit } \\
\mathbf{y}\end{array}$ & $\begin{array}{c}\text { Oral } \\
\text { Rat } \\
* * \text { LD50 } \\
\text { mg/kg }\end{array}$ \\
\hline $\mathbf{4 a}$ & $3.3 \times 10^{-3}$ & High & Yes & Yes & No & 4.0 & 1630 \\
\hline $4 e$ & $2.1 \times 10^{-3}$ & High & Yes & Yes & No & 4.6 & 1200 \\
\hline
\end{tabular}




\begin{tabular}{cccccccc}
\hline $\begin{array}{c}\text { Benznidaz } \\
\text { ole }\end{array}$ & $2.3 \times 10^{-3}$ & High & No & No & No & 0.5 & 517 \\
\hline Curcumin & $4.2 \times 10^{-3}$ & High & No & No & No & 3.0 & 1015 \\
\hline
\end{tabular}

*P-glycoprotein substrate, **Calculated by Toxicity Estimation Software Tool (TEST)

\section{Computational study}

The docking studies showed that the predicted interaction site is similar to the curcumin. However, the conformation for curcumin is better than in the $\mathbf{6} \mathbf{b}$ analogue because of a $\pi$ $\pi$ interaction and hydrogen bond in the hydroxyl substitution in the aromatic ring. This interaction was not favorable in the $\mathbf{6 b}$ analog, but the conformation of $\mathbf{6 b}$ interact closer to an essential loop for the dimer stability (the total binding data in the supporting information). Also, compound $\mathbf{6 b}$ has no inhibition effect at $100 \mathrm{uM}$ in the human enzyme (HsTIM), demonstrating the selectivity of this molecule for TcTIM.

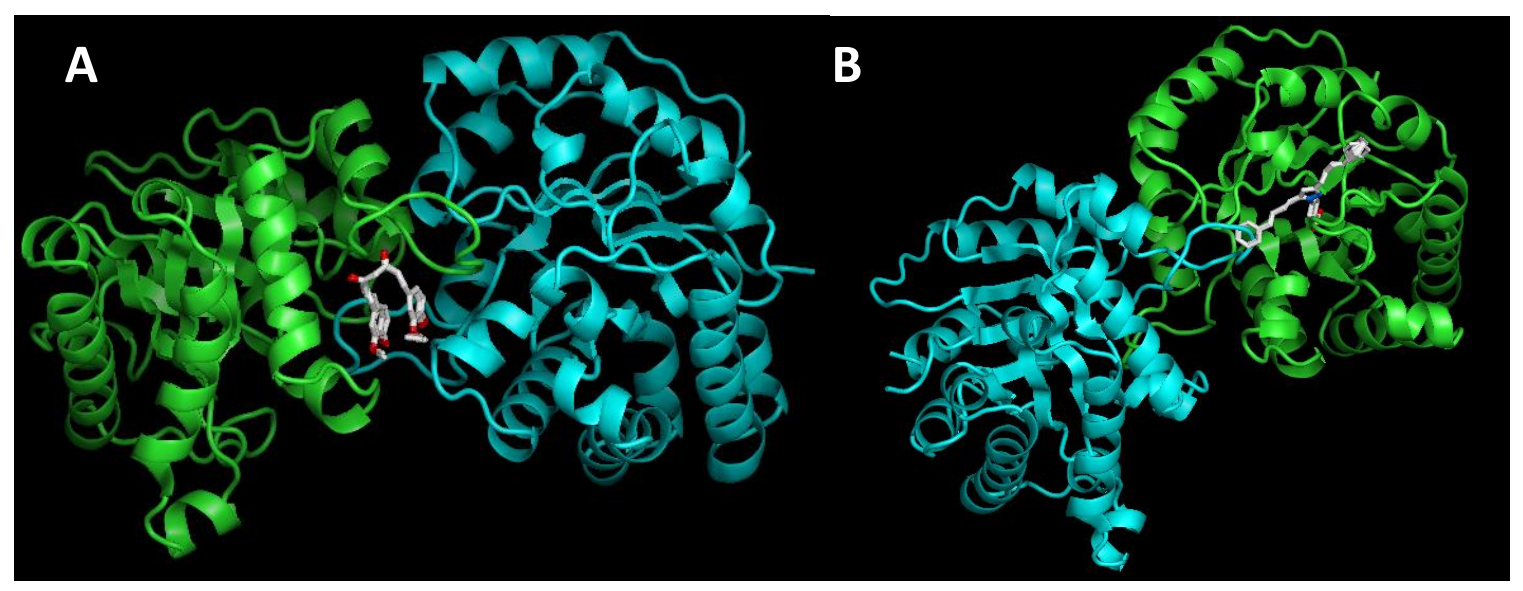

Fig. 2. Binding site interaction predicted by Docking, full energy calculations are in supporting information. A) is the binding site of curcumin and B) binding site of $\mathbf{6 b}$.

\section{Experimental part}

General

All reagents were purchased from Sigma-Aldrich, Alfa Aesar, and TCI and used without further purification. Melting points were determined with a Gallenkamp MFB-595 melting point apparatus. NMR spectra were recorded with a Bruker Avance $500 \mathrm{MHz}$ spectrometer 
operating at $500 \mathrm{MHz}\left({ }^{1} \mathrm{H}\right)$ and $125 \mathrm{MHz}\left({ }^{13} \mathrm{C}\right)$ or with a Bruker Avance $250 \mathrm{MHz}$ spectrometer operating at $250 \mathrm{MHz}\left({ }^{1} \mathrm{H}\right)$ and $62.5 \mathrm{MHz}\left({ }^{13} \mathrm{C}\right)$. Chemical shifts are reported in ppm relative to DMSO- $d_{6}\left({ }^{1} \mathrm{H}: \delta=2.50 \mathrm{ppm},{ }^{13} \mathrm{C}: \delta=39.52 \pm 0.06 \mathrm{ppm}\right)$. Elemental analyses were performed... Starting materials 1a-c, 1e-g and 1i,j were prepared following our published procedures $[32,34]$. Pyrazolines $\mathbf{2 a}$, 5a-c and pyrazoles 6a,b were prepared according to our published protocols without modifications [27,32-35].

Synthesis of 2,6-bis((E)-4-hydroxybenzylidene)cyclohexan-1-one 1d

A mixture of cyclohexanone $(0.98 \mathrm{~g}, 10 \mathrm{mmol})$ and 4-hydroxybenzaldehyde $(2.44 \mathrm{~g}, 20$ $\mathrm{mmol})$ in ethanol $(2 \mathrm{~mL})$ was stirred at $40{ }^{\circ} \mathrm{C} .0 .2 \mathrm{~mL}$ of concentrated hydrochloric acid (37\%) was added dropwise. The resulting clear solution was stirred at $40{ }^{\circ} \mathrm{C}$ for $24 \mathrm{~h}$. After cooling to room temperature, a small volume of ethanol $(6-8 \mathrm{~mL})$ was added and the precipitated solid was filtrated under vacuum. The crude product was washed with cold ethanol $(2 \times 6-8 \mathrm{~mL})$ and then recrystallized from ethanol to give the pure product as olive green solid.

Yield: $1.68 \mathrm{mg}(55 \%), \mathrm{mp},{ }^{1} \mathrm{H}$ NMR (250 MHz, DMSO- $\left.d_{6}\right): 1.71(2 \mathrm{H}$, quin, $J=5.4 \mathrm{~Hz}$, $\left.\mathrm{CH}_{2} \mathrm{CH}_{2} \mathrm{CH}_{2}\right), 2.85\left(4 \mathrm{H}, \mathrm{t}, J=5.4 \mathrm{~Hz}, \mathrm{CH}_{2} \mathrm{CH}_{2} \mathrm{CH}_{2}\right), 6.84(4 \mathrm{H}, J=8.6 \mathrm{~Hz}, \mathrm{Ph}), 7.41(4 \mathrm{H}$, $J=8.6 \mathrm{~Hz}, \mathrm{Ph}), 7.54(2 \mathrm{H}, \mathrm{s}, \mathrm{CH}=\mathrm{C}), 9.93(2 \mathrm{H}, \mathrm{brs}, \mathrm{OH})$.

\section{General synthetic procedure for compounds $\mathbf{2 a - b}$}

Pyrazoline $\mathbf{2 b}$ was prepared following the published synthetic protocol for $\mathbf{2 a}$ [27].

(E)-7-(3,4-dimethoxybenzylidene)-3-(3,4-dimethoxyphenyl)-2-pyridyl-3,3a,4,5,6,7hexahydro-2H-indazole $\mathbf{2 b}$

Yield: $138 \mathrm{mg}(57 \%), \mathrm{mp},{ }^{1} \mathrm{H}$ NMR (500 MHz, DMSO- $\left.d_{6}\right): 1.46\left(1 \mathrm{H}, \mathrm{m}, \mathrm{CH}_{2} \mathrm{CH}_{2} \mathrm{CH}_{2} \mathrm{CH}\right)$, $1.67\left(1 \mathrm{H}, \mathrm{m}, \mathrm{CH}_{2} \mathrm{CH}_{2} \mathrm{CH}_{2} \mathrm{CH}\right), 1.86\left(1 \mathrm{H}, \mathrm{m}, \mathrm{CH}_{2} \mathrm{CH}_{2} \mathrm{CH}_{2} \mathrm{CH}\right), 2.10(1 \mathrm{H}, \mathrm{m}$, $\left.\mathrm{CH}_{2} \mathrm{CH}_{2} \mathrm{CH}_{2} \mathrm{CH}\right), 2.50\left(1 \mathrm{H}, \mathrm{m}, \mathrm{CH}_{2} \mathrm{CH}_{2} \mathrm{CH}_{2} \mathrm{CH}\right), 2.92\left(2 \mathrm{H}, \mathrm{m}, \mathrm{CH}_{2} \mathrm{CH}_{2} \mathrm{CH}_{2} \mathrm{CH}\right.$ and $\left.\mathrm{CH}_{2} \mathrm{CH}_{2} \mathrm{CH}_{2} \mathrm{CH}\right), 3.72\left(6 \mathrm{H}, \mathrm{s}, \mathrm{OCH}_{3}\right), 3.77\left(6 \mathrm{H}, \mathrm{s}, \mathrm{OCH}_{3}\right), 4.90(1 \mathrm{H}, \mathrm{d}, J=10.6 \mathrm{~Hz}, \mathrm{CH}-$ N), 6.73 (1H, br, Pyr), 6.83 (1H, d, J= 7.5, Ph), 6.89 (2H, d, $J=6.5 \mathrm{~Hz}, \mathrm{Ph}), 6.98$ (2H, br, $\mathrm{Ph}), 7.02$ (1H, br, Ph), 7.12 (1H, s, CH=C), 7.39 (1H, d, J=7.5 Hz, Pyr), 7.59 (1H, br t, $J$ $=6.8 \mathrm{~Hz}, \mathrm{Pyr}), 7.94(1 \mathrm{H}, \mathrm{br} \mathrm{d}, J=3.6 \mathrm{~Hz}, \mathrm{Pyr}),{ }^{13} \mathrm{C}$ NMR $\left(62.5 \mathrm{MHz}, \mathrm{DMSO}-d_{6}\right): 23.8$ $\left(\mathrm{CH}_{2} \mathrm{CH}_{2} \mathrm{CH}_{2} \mathrm{CH}\right), 28.4\left(\mathrm{CH}_{2} \mathrm{CH}_{2} \mathrm{CH}_{2} \mathrm{CH}\right), 28.9\left(\mathrm{CH}_{2} \mathrm{CH}_{2} \mathrm{CH}_{2} \mathrm{CH}\right), 55.48(2 \times \mathrm{MeO}), 55.5$ $\left.(2 \times \mathrm{MeO}), 56.1\left(\mathrm{CH}_{2} \mathrm{CH}_{2} \mathrm{CH}_{2} \mathrm{CH}\right), 70.1(\mathrm{CH}-\mathrm{N})\right), 109.5(\mathrm{Ph}), 110.7(\mathrm{Pyr}), 111.6(\mathrm{Ph})$, $111.9(\mathrm{Ph}), 113.4(\mathrm{Ph}), 115.3(\mathrm{Pyr}), 117.7(\mathrm{Ph}), 122.2(\mathrm{Ph}), 125.9(C \mathrm{H}=\mathrm{C}), 128.9(\mathrm{Ph})$, $129.0(\mathrm{Ph}), 136.0(\mathrm{CH}=C), 136.9(\mathrm{Pyr}), 147.1(\mathrm{Pyr}), 147.6(\mathrm{Ph}), 148.3(\mathrm{Ph}), 148.4(\mathrm{Ph})$, $148.8(\mathrm{Ph}), 155.4(C=\mathrm{N}), 157.2(\mathrm{Pyr})$. 


\section{General synthetic procedure for compounds 3a-c}

Compound 1a-c (0.50 mmol ) and 4-fluorophenylhydrazine hydrochloride (244 mg, 1.50 $\mathrm{mmol})$ were added in anhydrous ethanol $(10 \mathrm{~mL})$ containing sodium ethoxide $(3.00 \mathrm{mmol})$ prepared in situ by addition of $\mathrm{Na}^{\mathrm{o}}(69 \mathrm{mg}, 3.00 \mathrm{mmol})$ in anhydrous ethanol $(10 \mathrm{~mL})$. The reaction mixture was stirred under reflux for $24 \mathrm{~h}$.

(E)-7-(4-methoxybenzylidene)-3-(4-methoxyphenyl)-2-(4-fluorophenyl)-3,3a,4,5,6,7hexahydro-2H-indazole $3 \mathbf{a}$

Yield: $138 \mathrm{mg}$ (62\%), mp, ${ }^{1} \mathrm{H}$ NMR (500 MHz, DMSO- $\left.d_{6}\right): 1.36-1.43$ (1H, m, $\left.\mathrm{CH}_{2} \mathrm{CH}_{2} \mathrm{CH}_{2} \mathrm{CH}\right), \quad 1.61-1.68 \quad\left(1 \mathrm{H}, \quad \mathrm{m}, \quad \mathrm{CH}_{2} \mathrm{CH}_{2} \mathrm{CH}_{2} \mathrm{CH}\right), \quad 1.85-1.87 \quad(1 \mathrm{H}, \quad \mathrm{m}$, $\left.\mathrm{CH}_{2} \mathrm{CH}_{2} \mathrm{CH}_{2} \mathrm{CH}\right), \quad 1.99-2.00 \quad\left(1 \mathrm{H}, \quad \mathrm{m}, \quad \mathrm{CH}_{2} \mathrm{CH}_{2} \mathrm{CH}_{2} \mathrm{CH}\right), \quad 2.40-2.46 \quad(1 \mathrm{H}, \mathrm{m}$, $\left.\mathrm{CH}_{2} \mathrm{CH}_{2} \mathrm{CH}_{2} \mathrm{CH}\right), 2.85-2.91\left(2 \mathrm{H}, \mathrm{m}, \mathrm{CH}_{2} \mathrm{CH}_{2} \mathrm{CH}_{2} \mathrm{CH}\right.$ and $\left.\mathrm{CH}_{2} \mathrm{CH}_{2} \mathrm{CH}_{2} \mathrm{CH}\right), 3.75(3 \mathrm{H}$, s, $\left.\mathrm{OCH}_{3}\right), 3.78\left(3 \mathrm{H}, \mathrm{s}, \mathrm{OCH}_{3}\right), 4.56(1 \mathrm{H}, \mathrm{d}, J=12.6 \mathrm{~Hz}, \mathrm{CH}-\mathrm{N}), 6.93-6.99(8 \mathrm{H}, \mathrm{m}, \mathrm{Ph}), 7.11$ $(1 \mathrm{H}, \mathrm{s}, \mathrm{CH}=\mathrm{C}), 7.33-7.38(4 \mathrm{H}, \mathrm{m}, \mathrm{Ph}),{ }^{13} \mathrm{C} \mathrm{NMR}\left(62.5 \mathrm{MHz}, \mathrm{DMSO}-d_{6}\right): 23.6$ $\left(\mathrm{CH}_{2} \mathrm{CH}_{2} \mathrm{CH}_{2} \mathrm{CH}\right), 28.1\left(\mathrm{CH}_{2} \mathrm{CH}_{2} \mathrm{CH}_{2} \mathrm{CH}\right), 28.3\left(\mathrm{CH}_{2} \mathrm{CH}_{2} \mathrm{CH}_{2} \mathrm{CH}\right), 55.07(\mathrm{MeO}), 55.13$ $(\mathrm{MeO}), 56.6\left(\mathrm{CH}_{2} \mathrm{CH}_{2} \mathrm{CH}_{2} \mathrm{CH}\right), 73.0(\mathrm{CH}-\mathrm{N}), 113.8(\mathrm{Ph}), 114.5(\mathrm{Ph}), 115.0\left(\mathrm{~d},{ }^{2} J_{\mathrm{C}-\mathrm{F}}=22.0\right.$ $\mathrm{Hz}, \mathrm{Ph}), 115.9\left(\mathrm{~d},{ }^{3} J_{\mathrm{C}-\mathrm{F}}=7.5 \mathrm{~Hz}, \mathrm{Ph}\right), 125.2(\mathrm{CH}=\mathrm{C}), 127.2(\mathrm{Ph}), 128.6(\mathrm{Ph}), 128.7$ $(\mathrm{CH}=C), 130.9(\mathrm{Ph}), 133.5(\mathrm{Ph}), 143.5\left(\mathrm{~d},{ }^{4} J_{\mathrm{C}-\mathrm{F}}=2.0 \mathrm{~Hz}, \mathrm{Ph}\right), 153.6(C=\mathrm{N}), 156.4\left(\mathrm{~d},{ }^{1} J_{\mathrm{C}-}\right.$ $\mathrm{F}=236.0 \mathrm{~Hz}), 158.5(\mathrm{Ph}), 158.7(\mathrm{Ph})$.

(E)-7-(3,4-dimethoxybenzylidene)-3-(3,4-dimethoxyphenyl)-2-(4-fluorophenyl)3,3a,4,5,6,7-hexahydro-2H-indazole $\mathbf{3 b}$

Yield: $156 \mathrm{mg}$ (62\%), mp, ${ }^{1} \mathrm{H}$ NMR (500 MHz, DMSO- $\left.d_{6}\right): 1.37-1.45$ (1H, m, $\left.\mathrm{CH}_{2} \mathrm{CH}_{2} \mathrm{CH}_{2} \mathrm{CH}\right), \quad 1.61-1.69 \quad\left(1 \mathrm{H}, \quad \mathrm{m}, \quad \mathrm{CH}_{2} \mathrm{CH}_{2} \mathrm{CH}_{2} \mathrm{CH}\right), \quad 1.86-1.89 \quad(1 \mathrm{H}, \quad \mathrm{m}$, $\mathrm{CH}_{2} \mathrm{CH}_{2} \mathrm{CH}_{2} \mathrm{CH}$ ), 2.01-2.02 (1H, m, $\left.\mathrm{CH}_{2} \mathrm{CH}_{2} \mathrm{CH}_{2} \mathrm{CH}\right), 2.50\left(1 \mathrm{H}, \mathrm{m}, \mathrm{CH}_{2} \mathrm{CH}_{2} \mathrm{CH}_{2} \mathrm{CH}\right)$, 2.91-2.97 (2H, m, $\mathrm{CH}_{2} \mathrm{CH}_{2} \mathrm{CH}_{2} \mathrm{CH}$ and $\left.\mathrm{CH}_{2} \mathrm{CH}_{2} \mathrm{CH}_{2} \mathrm{CH}\right), 3.74\left(3 \mathrm{H}, \mathrm{s}, \mathrm{OCH}_{3}\right), 3.75(6 \mathrm{H}, \mathrm{s}$, $\left.\mathrm{OCH}_{3}\right), 3.78\left(6 \mathrm{H}, \mathrm{s}, \mathrm{OCH}_{3}\right), 4.53(1 \mathrm{H}, \mathrm{d}, J=12.6 \mathrm{~Hz}, \mathrm{CH}-\mathrm{N}), 6.95-7.01(10 \mathrm{H}, \mathrm{m}, \mathrm{Ph}), 7.13$ $(1 \mathrm{H}, \mathrm{s}, \mathrm{CH}=\mathrm{C}),{ }^{13} \mathrm{C} \mathrm{NMR}\left(62.5 \mathrm{MHz}, \mathrm{DMSO}-d_{6}\right): 23.6\left(\mathrm{CH}_{2} \mathrm{CH}_{2} \mathrm{CH}_{2} \mathrm{CH}\right), 28.19$ $\left(\mathrm{CH}_{2} \mathrm{CH}_{2} \mathrm{CH}_{2} \mathrm{CH}\right), 28.24\left(\mathrm{CH}_{2} \mathrm{CH}_{2} \mathrm{CH}_{2} \mathrm{CH}\right), 55.5(\mathrm{MeO}), 56.5\left(\mathrm{CH}_{2} \mathrm{CH}_{2} \mathrm{CH}_{2} \mathrm{CH}\right), 73.5$ $(C H-N), 109.4(\mathrm{Ph}), 111.6(\mathrm{Ph}), 112.2(\mathrm{Ph}), 113.3(\mathrm{Ph}), 115.0\left(\mathrm{~d},{ }^{2} J_{\mathrm{C}-\mathrm{F}}=22.0 \mathrm{~Hz}, \mathrm{Ph}\right)$, $115.9\left(\mathrm{~d},{ }^{3} J_{\mathrm{C}-\mathrm{F}}=7.5 \mathrm{~Hz}, \mathrm{Ph}\right), 118.1(\mathrm{Ph}), 122.2(\mathrm{Ph}), 125.6(\mathrm{CH}=\mathrm{C}), 128.8(\mathrm{CH}=C), 128.9$ $(\mathrm{Ph}), 134.0(\mathrm{Ph}), 143.8\left(\mathrm{~d},{ }^{4} J_{\mathrm{C}-\mathrm{F}}=2.0 \mathrm{~Hz}, \mathrm{Ph}\right), 148.21(\mathrm{Ph}), 148.24(\mathrm{Ph}), 148.4(\mathrm{Ph}), 149.2$ $(\mathrm{Ph}), 153.7(C=\mathrm{N}), 156.4\left(\mathrm{~d},{ }^{1} J_{\mathrm{C}-\mathrm{F}}=236.0 \mathrm{~Hz}\right)$.

(E)-7-(3,4,5-trimethoxybenzylidene)-3-(3,4,5-trimethoxyphenyl)-2-(4-fluorophenyl)3,3a,4,5,6,7-hexahydro-2H-indazole 3c 
Yield: $167 \mathrm{mg}$ (59\%), mp, ${ }^{1} \mathrm{H}$ NMR (500 MHz, DMSO- $\left.d_{6}\right)$ : 1.39-1.46 (1H, m, $\left.\mathrm{CH}_{2} \mathrm{CH}_{2} \mathrm{CH}_{2} \mathrm{CH}\right), \quad 1.62-1.70 \quad\left(1 \mathrm{H}, \quad \mathrm{m}, \quad \mathrm{CH}_{2} \mathrm{CH}_{2} \mathrm{CH}_{2} \mathrm{CH}\right), \quad 1.87-1.89 \quad(1 \mathrm{H}, \quad \mathrm{m}$, $\left.\mathrm{CH}_{2} \mathrm{CH}_{2} \mathrm{CH}_{2} \mathrm{CH}\right), 2.06-2.08\left(1 \mathrm{H}, \mathrm{m}, \mathrm{CH}_{2} \mathrm{CH}_{2} \mathrm{CH}_{2} \mathrm{CH}\right), 2.50\left(1 \mathrm{H}, \mathrm{m}, \mathrm{CH}_{2} \mathrm{CH}_{2} \mathrm{CH}_{2} \mathrm{CH}\right)$, 2.93-2.99 (2H, m, $\mathrm{CH}_{2} \mathrm{CH}_{2} \mathrm{CH}_{2} \mathrm{CH}$ and $\left.\mathrm{CH}_{2} \mathrm{CH}_{2} \mathrm{CH}_{2} \mathrm{CH}\right), 3.66\left(3 \mathrm{H}, \mathrm{s}, \mathrm{OCH}_{3}\right), 3.68(3 \mathrm{H}, \mathrm{s}$, $\left.\mathrm{OCH}_{3}\right), 3.76\left(6 \mathrm{H}, \mathrm{s}, \mathrm{OCH}_{3}\right), 3.79\left(6 \mathrm{H}, \mathrm{s}, \mathrm{OCH}_{3}\right), 4.54(1 \mathrm{H}, \mathrm{d}, J=12.6 \mathrm{~Hz}, \mathrm{CH}-\mathrm{N}), 6.71$ $(2 \mathrm{H}, \mathrm{s}, \mathrm{Ph}), 6.73$ (2H, s, Ph), 6.99-7.04 (4H, m, Ph), 7.14 (1H, s, CH=C), ${ }^{13} \mathrm{C}$ NMR (62.5 MHz, DMSO-d $)$ : $23.6\left(\mathrm{CH}_{2} \mathrm{CH}_{2} \mathrm{CH}_{2} \mathrm{CH}\right), 28.2\left(\mathrm{CH}_{2} \mathrm{CH}_{2} \mathrm{CH}_{2} \mathrm{CH}\right), 28.3\left(\mathrm{CH}_{2} \mathrm{CH}_{2} \mathrm{CH}_{2} \mathrm{CH}\right)$, $55.9(4 \times \mathrm{MeO}), 56.4\left(\mathrm{CH}_{2} \mathrm{CH}_{2} \mathrm{CH}_{2} \mathrm{CH}\right), 59.9(2 \times \mathrm{MeO}), 60.1(2 \times \mathrm{MeO}), 73.9(\mathrm{CH}-\mathrm{N})$, $102.9(\mathrm{Ph}), 107.1(\mathrm{Ph}), 112.2(\mathrm{Ph}), 113.3(\mathrm{Ph}), 115.2\left(\mathrm{~d},{ }^{2} J_{\mathrm{C}-\mathrm{F}}=22.0 \mathrm{~Hz}, \mathrm{Ph}\right), 116.0\left(\mathrm{~d},{ }^{3} J_{\mathrm{C}-}\right.$ $\mathrm{F}=7.5 \mathrm{~Hz}, \mathrm{Ph}), 125.9(C \mathrm{H}=\mathrm{C}), 130.1(\mathrm{Ph}), 131.7(\mathrm{Ph}), 136.6(\mathrm{Ph}), 137.0(\mathrm{CH}=C), 137.5$ $(\mathrm{Ph}), 143.8\left(\mathrm{~d},{ }^{4} J_{\mathrm{C}-\mathrm{F}}=2.0 \mathrm{~Hz}, \mathrm{Ph}\right), 152.6(\mathrm{Ph}), 153.4(\mathrm{Ph}), 153.6(\mathrm{Ph}), 149.2(\mathrm{Ph}), 153.7$ $(C=\mathrm{N}), 156.4\left(\mathrm{~d},{ }^{1} J_{\mathrm{C}-\mathrm{F}}=236.0 \mathrm{~Hz}\right)$.

\section{General synthetic procedure for compounds 4a-e}

(E)-7-(4-methoxybenzylidene)-3-(4-methoxyphenyl)-3,3a,4,5,6,7-hexahydro-2H-indazole 4a $[37,38]$

Yield: $134 \mathrm{mg}$ (77\%), mp, ${ }^{1} \mathrm{H}$ NMR (500 MHz, DMSO- $\left.d_{6}\right): 1.30-1.38$ (1H, m, $\left.\mathrm{CH}_{2} \mathrm{CH}_{2} \mathrm{CH}_{2} \mathrm{CH}\right), 1.43-1.50\left(1 \mathrm{H}, \mathrm{m}, \mathrm{CH}_{2} \mathrm{CH}_{2} \mathrm{CH}_{2} \mathrm{CH}\right), 1.83-1.89\left(2 \mathrm{H}, \mathrm{m}, \mathrm{CH}_{2} \mathrm{CH}_{2} \mathrm{CH}_{2} \mathrm{CH}\right.$ and $\left.\mathrm{CH}_{2} \mathrm{CH}_{2} \mathrm{CH}_{2} \mathrm{CH}\right), 2.34-2.39\left(1 \mathrm{H}, \mathrm{m}, \mathrm{CH}_{2} \mathrm{CH}_{2} \mathrm{CH}_{2} \mathrm{CH}\right), 2.55-2.61(1 \mathrm{H}, \mathrm{m}$, $\left.\mathrm{CH}_{2} \mathrm{CH}_{2} \mathrm{CH}_{2} \mathrm{CH}\right), 2.81-2.84\left(1 \mathrm{H}, \mathrm{m}, \mathrm{CH}_{2} \mathrm{CH}_{2} \mathrm{CH}_{2} \mathrm{CH}\right), 3.74\left(3 \mathrm{H}, \mathrm{s}, \mathrm{OCH}_{3}\right), 3.77(3 \mathrm{H}, \mathrm{s}$, $\left.\mathrm{OCH}_{3}\right), 4.29(1 \mathrm{H}, \mathrm{dd}, J=14.2 \mathrm{~Hz} / 5.0 \mathrm{~Hz}, \mathrm{CH}-\mathrm{N}), 6.91(2 \mathrm{H}, \mathrm{d}, J=8.6 \mathrm{~Hz}, \mathrm{Ph}), 6.94$ (6.91 $(2 \mathrm{H}, \mathrm{d}, J=8.6 \mathrm{~Hz}, \mathrm{Ph}), 6.95(1 \mathrm{H}, \mathrm{s}, \mathrm{CH}=\mathrm{C}), 7.26(1 \mathrm{H}, \mathrm{d}, J=5.0 \mathrm{~Hz}, \mathrm{NH}), 7.31(2 \mathrm{H}, \mathrm{d}, J$ $=8.6 \mathrm{~Hz}, \mathrm{Ph}), 7.35(2 \mathrm{H}, \mathrm{d}, J=8.6 \mathrm{~Hz}, \mathrm{Ph})$

(E)-7-(3,4-dimethoxybenzylidene)-3-(3,4-dimethoxyphenyl)-3,3a,4,5,6,7-hexahydro-2Hindazole $\mathbf{4 b}$ [39]

Yield: $136 \mathrm{mg}$ (67\%), mp, ${ }^{1} \mathrm{H}$ NMR (500 MHz, DMSO- $\left.d_{6}\right):$ 1.31-1.39 (1H, m, $\left.\mathrm{CH}_{2} \mathrm{CH}_{2} \mathrm{CH}_{2} \mathrm{CH}\right), \quad 1.44-1.51 \quad\left(1 \mathrm{H}, \quad \mathrm{m}, \quad \mathrm{CH}_{2} \mathrm{CH}_{2} \mathrm{CH}_{2} \mathrm{CH}\right), \quad 1.84-1.86 \quad(1 \mathrm{H}, \quad \mathrm{m}$, $\left.\mathrm{CH}_{2} \mathrm{CH}_{2} \mathrm{CH}_{2} \mathrm{CH}\right), \quad 1.90-1.91 \quad\left(1 \mathrm{H}, \quad \mathrm{m}, \quad \mathrm{CH}_{2} \mathrm{CH}_{2} \mathrm{CH}_{2} \mathrm{CH}\right), \quad 2.36-2.42 \quad(1 \mathrm{H}, \quad \mathrm{m}$, $\left.\mathrm{CH}_{2} \mathrm{CH}_{2} \mathrm{CH}_{2} \mathrm{CH}\right), \quad 2.59-2.64 \quad\left(1 \mathrm{H}, \quad \mathrm{m}, \quad \mathrm{CH}_{2} \mathrm{CH}_{2} \mathrm{CH}_{2} \mathrm{CH}\right), \quad 2.86-2.89 \quad(1 \mathrm{H}, \quad \mathrm{m}$, $\left.\mathrm{CH}_{2} \mathrm{CH}_{2} \mathrm{CH}_{2} \mathrm{CH}\right), 3.74\left(3 \mathrm{H}, \mathrm{s}, \mathrm{OCH}_{3}\right), 3.76\left(9 \mathrm{H}, \mathrm{s}, \mathrm{OCH}_{3}\right), 4.29(1 \mathrm{H}, \mathrm{dd}, J=14.2 \mathrm{~Hz} / 5.0$ $\mathrm{Hz}, \mathrm{CH}-\mathrm{N}), 6.91-6.96$ (6H, m, Ph), $7.04(1 \mathrm{H}, \mathrm{s}, \mathrm{CH}=\mathrm{C}), 7.27(1 \mathrm{H}, \mathrm{d}, J=5.0 \mathrm{~Hz}, \mathrm{NH})$.

(E)-7-(3,4,5-trimethoxybenzylidene)-3-(3,4,5-trimethoxyphenyl)-3,3a,4,5,6,7-hexahydro$2 \mathrm{H}$-indazole $\mathbf{4 c}$ 
Yield: $138 \mathrm{mg}$ (59\%), mp, ${ }^{1} \mathrm{H}$ NMR (500 MHz, DMSO- $\left.d_{6}\right): 1.32-1.40(1 \mathrm{H}, \mathrm{m}$, $\left.\mathrm{CH}_{2} \mathrm{CH}_{2} \mathrm{CH}_{2} \mathrm{CH}\right), \quad 1.47-1.54 \quad\left(1 \mathrm{H}, \quad \mathrm{m}, \quad \mathrm{CH}_{2} \mathrm{CH}_{2} \mathrm{CH}_{2} \mathrm{CH}\right), \quad 1.85-1.87 \quad(1 \mathrm{H}, \quad \mathrm{m}$, $\left.\mathrm{CH}_{2} \mathrm{CH}_{2} \mathrm{CH}_{2} \mathrm{CH}\right), \quad 1.95-1.97 \quad\left(1 \mathrm{H}, \quad \mathrm{m}, \quad \mathrm{CH}_{2} \mathrm{CH}_{2} \mathrm{CH}_{2} \mathrm{CH}\right), \quad 2.41-2.46 \quad(1 \mathrm{H}, \quad \mathrm{m}$, $\left.\mathrm{CH}_{2} \mathrm{CH}_{2} \mathrm{CH}_{2} \mathrm{CH}\right), \quad 2.60-2.67 \quad\left(1 \mathrm{H}, \quad \mathrm{m}, \quad \mathrm{CH}_{2} \mathrm{CH}_{2} \mathrm{CH}_{2} \mathrm{CH}\right), \quad 2.89-2.92 \quad(1 \mathrm{H}, \quad \mathrm{m}$, $\left.\mathrm{CH}_{2} \mathrm{CH}_{2} \mathrm{CH}_{2} \mathrm{CH}\right), 3.64\left(3 \mathrm{H}, \mathrm{s}, \mathrm{OCH}_{3}\right), 3.67\left(3 \mathrm{H}, \mathrm{s}, \mathrm{OCH}_{3}\right), 3.78\left(12 \mathrm{H}, \mathrm{s}, \mathrm{OCH}_{3}\right), 4.32(1 \mathrm{H}$, dd, $J=14.2 \mathrm{~Hz} / 5.0 \mathrm{~Hz}, \mathrm{CH}-\mathrm{N}), 6.65$ (2H, s, Ph), 6.73 (2H, s, Ph), 6.96 (1H, s, CH=C), $7.34(1 \mathrm{H}, \mathrm{d}, J=5.0 \mathrm{~Hz}, \mathrm{NH}) .{ }^{13} \mathrm{C} \mathrm{NMR}\left(125 \mathrm{MHz}, \mathrm{DMSO}-d_{6}\right): 23.9\left(\mathrm{CH}_{2} \mathrm{CH}_{2} \mathrm{CH}_{2} \mathrm{CH}\right)$, $28.1\left(\mathrm{CH}_{2} \mathrm{CH}_{2} \mathrm{CH}_{2} \mathrm{CH}\right.$ and $\left.\mathrm{CH}_{2} \mathrm{CH}_{2} \mathrm{CH}_{2} \mathrm{CH}\right), 52.8\left(\mathrm{CH}_{2} \mathrm{CH}_{2} \mathrm{CH}_{2} \mathrm{CH}\right), 55.8(2 \times \mathrm{MeO}), 55.9$ $(2 \times \mathrm{MeO}), 59.9(\mathrm{MeO}), 60.0(\mathrm{MeO}), 72.4(\mathrm{CH}-\mathrm{N}), 104.0(\mathrm{Ph}), 106.9(\mathrm{Ph}), 124.2(\mathrm{CH}=\mathrm{C})$, $131.1(\mathrm{Ph}), 132.0(\mathrm{Ph}), 136.6(\mathrm{Ph}), 136.8(\mathrm{Ph}), 137.0(\mathrm{CH}=C), 152.6(\mathrm{Ph}), 152.8(\mathrm{Ph}), 153.6$ $(C=\mathrm{N})$.

(E)-7-(4-hydroxybenzylidene)-3-(4-hydroxyphenyl)-3,3a,4,5,6,7-hexahydro-2H-indazole 4d $[39,40]$

Yield: $138 \mathrm{mg}$ (59\%), mp, ${ }^{1} \mathrm{H}$ NMR (500 MHz, DMSO- $\left.d_{6}\right)$ : 1.29-1.37 (1H, m, $\left.\mathrm{CH}_{2} \mathrm{CH}_{2} \mathrm{CH}_{2} \mathrm{CH}\right), 1.40-1.47\left(1 \mathrm{H}, \mathrm{m}, \mathrm{CH}_{2} \mathrm{CH}_{2} \mathrm{CH}_{2} \mathrm{CH}\right), 1.82-1.88\left(2 \mathrm{H}, \mathrm{m}, \mathrm{CH}_{2} \mathrm{CH}_{2} \mathrm{CH}_{2} \mathrm{CH}\right.$ and $\left.\mathrm{CH}_{2} \mathrm{CH}_{2} \mathrm{CH}_{2} \mathrm{CH}\right), 2.31-2.36\left(1 \mathrm{H}, \quad \mathrm{m}, \mathrm{CH}_{2} \mathrm{CH}_{2} \mathrm{CH}_{2} \mathrm{CH}\right), 2.52-2.57(1 \mathrm{H}, \mathrm{m}$, $\left.\mathrm{CH}_{2} \mathrm{CH}_{2} \mathrm{CH}_{2} \mathrm{CH}\right), 2.81-2.84\left(1 \mathrm{H}, \mathrm{m}, \mathrm{CH}_{2} \mathrm{CH}_{2} \mathrm{CH}_{2} \mathrm{CH}\right), 4.23(1 \mathrm{H}, \mathrm{dd}, J=14.2 \mathrm{~Hz} / 5.0 \mathrm{~Hz}$, $\mathrm{CH}-\mathrm{N}), 6.73(2 \mathrm{H}, \mathrm{d}, J=8.6 \mathrm{~Hz}, \mathrm{Ph}), 6.76(6.91(2 \mathrm{H}, \mathrm{d}, J=8.6 \mathrm{~Hz}, \mathrm{Ph}), 6.90(1 \mathrm{H}, \mathrm{s}, \mathrm{CH}=\mathrm{C})$, $7.17(1 \mathrm{H}, \mathrm{d}, J=5.0 \mathrm{~Hz}, \mathrm{NH}), 7.19-7.23(4 \mathrm{H}$, two overlapped d, $J=8.6 \mathrm{~Hz}, \mathrm{Ph}), 9.31(1 \mathrm{H}$, br, $\mathrm{OH}), 9.53(1 \mathrm{H}, \mathrm{br}, \mathrm{OH})$.

(E)-7-(4-fluorobenzylidene)-3-(4-fluorophenyl)-3,3a,4,5,6,7-hexahydro-2H-indazole $\mathbf{4 e}$ [39]

Yield: $139 \mathrm{mg}$ (86\%), mp, ${ }^{1} \mathrm{H}$ NMR (500 MHz, DMSO- $\left.d_{6}\right): 1.32-1.40(1 \mathrm{H}, \mathrm{m}$, $\left.\mathrm{CH}_{2} \mathrm{CH}_{2} \mathrm{CH}_{2} \mathrm{CH}\right), \quad 1.47-1.52 \quad\left(1 \mathrm{H}, \quad \mathrm{m}, \quad \mathrm{CH}_{2} \mathrm{CH}_{2} \mathrm{CH}_{2} \mathrm{CH}\right), \quad 1.83-1.86 \quad(1 \mathrm{H}, \quad \mathrm{m}$, $\left.\mathrm{CH}_{2} \mathrm{CH}_{2} \mathrm{CH}_{2} \mathrm{CH}\right), \quad 1.90-1.92 \quad\left(1 \mathrm{H}, \quad \mathrm{m}, \quad \mathrm{CH}_{2} \mathrm{CH}_{2} \mathrm{CH}_{2} \mathrm{CH}\right), \quad 2.36-2.42 \quad(1 \mathrm{H}, \quad \mathrm{m}$, $\left.\mathrm{CH}_{2} \mathrm{CH}_{2} \mathrm{CH}_{2} \mathrm{CH}\right), \quad 2.59-2.65 \quad\left(1 \mathrm{H}, \quad \mathrm{m}, \quad \mathrm{CH}_{2} \mathrm{CH}_{2} \mathrm{CH}_{2} \mathrm{CH}\right), \quad 2.79-2.82 \quad(1 \mathrm{H}, \quad \mathrm{m}$, $\left.\mathrm{CH}_{2} \mathrm{CH}_{2} \mathrm{CH}_{2} \mathrm{CH}\right), 4.38(1 \mathrm{H}, \mathrm{dd}, J=14.2 \mathrm{~Hz} / 5.0 \mathrm{~Hz}, \mathrm{CH}-\mathrm{N}), 7.00(1 \mathrm{H}, \mathrm{s}, \mathrm{CH}=\mathrm{C}), 7.17(2 \mathrm{H}$, $\mathrm{d}, J=9.0 \mathrm{~Hz}, \mathrm{Ph}), 7.21(2 \mathrm{H}, \mathrm{d}, J=9.0 \mathrm{~Hz}, \mathrm{Ph}), 7.40-7.43(3 \mathrm{H}, \mathrm{m}, \mathrm{NH}$ and $\mathrm{Ph}), 7.46-7.49$ $(2 \mathrm{H}, \mathrm{m}, \mathrm{Ph})$.

\section{Inhibition of Triosephosphate Isomerase [9].}

Expression and purification of proteins: TcTIM and HsTIM were expressed in Escherichia coli and purified as described in the literature. After purification, the enzyme, dissolved in $100 \mathrm{mM}$ triethanolamine, $10 \mathrm{mM}$ EDTA, and $1 \mathrm{mM}$ dithiothreitol ( $\mathrm{pH}$ 8), was precipitated 
with ammonium sulfate $\left(75 \%\right.$ saturation) and stored at $4{ }^{\circ} \mathrm{C}$. Before use, extensive dialysis against $100 \mathrm{mM}$ triethanolamine/10 mM EDTA (pH 7.4) was performed. Protein concentration was determined by absorbance at $280 \mathrm{~nm}$ for TcTIM $\left(\varepsilon=33460 \mathrm{M}^{-1} \mathrm{~cm}^{-1}\right)$ and $H \operatorname{HTIM}\left(\varepsilon=33460 \mathrm{M}^{-1} \mathrm{~cm}^{-1}\right.$ ). Enzymatic activity was determined following the conversion of glyceraldehydes-3-phosphate into dihydroxyacetone phosphate in a coupled enzyme assay. The decrease in absorbance at $340 \mathrm{~nm}$ was followed in a multiplate reader VarioskanTM Flash Multimode Reader (Thermo ScientificTM, Waltham, MA, USA) at $38^{\circ} \mathrm{C}$. The reaction mixture $(1 \mathrm{~mL}, \mathrm{pH} 7.4)$ contained $100 \mathrm{mM}$ triethanolamine, $10 \mathrm{mM}$ EDTA, $0.2 \mathrm{mM} \mathrm{NADH}, 1 \mathrm{mM}$ glyceraldehydes-3-phosphate and 0.9 units of $\alpha$-glycerol phosphate dehydrogenase. The reaction was initiated by the addition of $5 \mathrm{ng} / \mathrm{mL}$ of the TIM of interest. For the inhibition studies, TIM was incubated at a concentration of 5 $\mathrm{mg} / \mathrm{mL}$ in a buffer containing $100 \mathrm{mM}$ triethanolamine, $10 \mathrm{mM}$ EDTA, $\mathrm{pH} 7.4$, and 10\% of DMSO at $37^{\circ} \mathrm{C}$ for $1 \mathrm{~h}$. The mixture also contained the compounds, dissolved in DMSO, at the indicated concentrations. After $1 \mathrm{~h}, 10 \mu \mathrm{L}$ was withdrawn and added to a final volume of $100 \mu \mathrm{L}$ of the reaction mixture for the activity assay. The inhibition assay was performed in a 96-well microplate. None of the molecules tested here affected the activity of $\alpha$ glycerol phosphate dehydrogenase, the enzyme used in the coupled assay. The $\mathrm{IC}_{50}$ value was taken as the concentration of drug needed to reduce the enzymatic activity to $50 \%$ by analysis using OriginLab8.5® sigmoidal regression (\% of enzymatic activity vs. the logarithm of the compound concentration). The experiments were performed in triplicate in two independent experiments.

\section{Docking [41].}

The crystal structure PDB ID 1TCD of TcTIM was used as a target in the subsequent docking studies. Compounds were modeled using their SMILES codes from the Chemoffice software. Then, both target protein and ligands were prepared using AutoDockTools v1.5.6: the polar hydrogen atoms were added, the non-polar hydrogens were merged, and the Gasteiger partial atomic charges were calculated. Finally, all the possible rotatable bonds were assigned for each compound. Four distinct docking experiments were then carried out with the program AutoDock Vina v1.1.2: a search on the entire surface of TcTIM in its dimeric and monomeric forms as well as a targeted docking in the active site only, with and without the flexibility of the side chains of the residues defining the binding pocket. Compounds were treated as fully flexible in each experiment. The search grid was defined accordingly to encompass the considered areas. 
A visual examination of the resulting poses was performed using PyMOL (Schrödinger, Delano Scientific, LLC, New York, NY, USA).

\section{Anti-Parasitic Test In Vitro [9].}

For the in vitro anti-T. cruzi activity, we used epimastigotes of the Tulahuen 2 strain (genotype TcVI) grown in an axenic medium (BHI-Tryptose). Cells from a 5-7-days-old culture were inoculated in fresh culture medium to give an initial concentration of $1 \times 10^{6}$ cells/mL. The absorbance at $600 \mathrm{~nm}$ of the cells in culture was measured every day. At day five, the medium was inoculated with different doses of the compounds $(25,12.5,6.25$, $3.13,1.6,0.8,0.4,0.2,0.1,0.05) \mu \mathrm{M}$ from a freshly prepared stock solution in DMSO (DMSO concentration in the culture milieu never exceeded $0.4 \%$ ). Control parasites were cultivated in $0.4 \%$ DMSO. Each concentration of the compound was evaluated in duplicate. At five days, the absorbance of the culture was measured and compared to the control and the IC50 values calculated for each compound using OriginLab8.5® sigmoidal regression. Each experiment was done in duplicate, and each concentration was tested in triplicate.

\section{Nonspecific In Vitro Cytotoxicity of Mammalian Cells [9].}

J774.1 murine macrophages (ATCC, USA) were grown in a DMEM culture medium containing $4 \mathrm{mM}$ L-glutamine and supplemented with $10 \%$ FCS. Cells were seeded in a 96-well plate $\left(5 \times 10^{4}\right.$ cells in $200 \mu \mathrm{L}$ culture medium) and incubated at $37{ }^{\circ} \mathrm{C}$ in a $5 \% \mathrm{CO}_{2}$ atmosphere for $48 \mathrm{~h}$, to allow cell adhesion before drug testing. Afterward, cells were exposed for $48 \mathrm{~h}$ to the compounds $(25-400 \mu \mathrm{M})$ or the vehicle for control $(0.4 \%$ DMSO), and additional controls (cells in medium) were used in each test. Cell viability was then assessed by measuring the mitochondria-dependent reduction of MTT (3-(4,5dimethylthiazol-2-yl)-2,5-diphenyltetrazolium bromide) to formazan. For this purpose, MTT in sterile PBS (0.2\% glucose), $\mathrm{pH} 7.4$, was added to the macrophages to achieve a final concentration of $0.1 \mathrm{mg} / \mathrm{mL}$, and the cells were incubated at $37{ }^{\circ} \mathrm{C}$ for $3 \mathrm{~h}$. After removing the medium, formazan crystals were dissolved in $180 \mu \mathrm{L}$ of DMSO and $20 \mu \mathrm{L}$ of MTT buffer ( $0.1 \mathrm{M}$ glycine, $0.1 \mathrm{M} \mathrm{NaCl}, 0.5 \mathrm{mM}$ EDTA, $\mathrm{pH} 10.5)$, and the absorbance at $560 \mathrm{~nm}$ was measured. The IC50 was defined as the drug concentration at which $50 \%$ of the cells were viable, relative to the control (no drug added), and was determined by analysis using OriginLab8.5® sigmoidal regression (\% of viable cells compared to the logarithm of the compound concentration). Tests were performed in triplicate.

Calculation of the Pharmacokinetic Parameters $[42,43]$. 
The predictions were made with the open-access SwissADME software (http://www.swissadme.ch), a tool that allows the prediction of different pharmacokinetic parameters such as water solubility, gastrointestinal absorption, skin penetrability, lipophilicity, bioavailability, etc (Figure 2S). The oral Lethal Doses 50 in Rat was estimated using the Toxicity Estimation Software Tool (TEST). For both of them were used the SMILES codes generated with the ChemBioOffice 2010 program.

\section{Conclusions}

Fifteen new compounds were synthesized and chemical and biological characterized against $T c$ TIM and epimastigotes of $T$. cruzi. One compound was a novel and selective TcTIM inhibitor, and two compounds were effective trypanosomicidal agents. The 16-fold (for 4a) and 6-fold (for 4e) higher potencies of these derivatives in comparison to their curcuminoids precursors make them an attractive and promising new family of trypanosomicidal compound. Also, compounds $4 \mathbf{a}$ and $\mathbf{4 e}$ can proceed to the next stage in the drug development process to an in vivo and metabolic stability studies.

\section{References}

[1] World Health Organization. Chagas disease (also known as American trypanosomiasis). Key facts. 11 March 2020.

[2] Viotti R, Vigliano C, Lococo B et al. Side effects of benznidazole as treatment in chronic Chagas disease: fears and realities. Expert Rev. Anti Infect. Ther. 7(2), 157163 (2009).

[3] Forsyth CJ, Hernandez S, Olmedo W et al. Safety profile of nifurtimox for treatment of Chagas disease in the United States. Clin. Infect. Dis. 63(8), 1056-1062 (2016).

[4] Chatelain E. Chagas disease research and development: Is there light at the end of the tunnel? Comput. Struct. Biotechnol. J. 15, 98-103 (2017).

[5] Sueth-Santiago V, Moraes JdBB, Sobral Alves ES, Vannier-Santos MA, Freire-deLima CG, Castro RN, et al. The Effectiveness of Natural Diarylheptanoids against Trypanosoma cruzi: Cytotoxicity, Ultrastructural Alterations and Molecular Modeling Studies. PLoS ONE 11(9), e0162926 (2016).

[6] Nagajyothi F, Zhao D, Weiss LM, Tanowitz HB. Curcumin treatment provides protection against Trypanosoma cruzi infection. Parasitol. Res. 110, 2491-2499 (2012).

[7] Anand P, Kunnumakkara AB, Newman RA, Aggarwal BB. Bioavailability of curcumin: problems and promises. Mol. Pharm. 4(6), 807-818 (2007). 
[8] Shetty D, Kim YJ, Shim H, Snyder JP. Eliminating the heart from the curcumin molecule: monocarbonyl curcumin mimics (MACs). Molecules 20, 249-292 (2015).

[9] Aguilera E, Varela J, Birriel E et al. Potent and selective inhibitors of Trypanosoma cruzi triosephosphate isomerase with concomitant inhibition of cruzipain: inhibition of parasite growth through multitarget activity. ChemMedChem 11, 1328-1338 (2016).

[10] Álvarez G, Perdomo C, Coronel C et al. Multi-anti-parasitic activity of arylidene ketones and thiazolidene hydrazines against Trypanosoma cruzi and Leishmania spp. Molecules 22, 709 (2017).

[11] Din ZU, Trapp MA, de Medeiros LS et al. Symmetrical and unsymmetrical substituted 2,5-diarylidene cyclohexanones as anti-parasitic compounds. Eur. J. Med. Chem. 155, 596-608 (2018).

[12] Marella A, Ali R, Alam T et al. Pyrazolines: a biological review. Mini-Rev. Med. Chem. 13, 921-931 (2013).

[13] Alex JM, Kumar R. 4,5-Dihydro-1H-pyrazole: an indispensable scaffold. J. Enzyme Inhib. Med. Chem. 29, 427-442 (2014).

[14] Shaaban MR, Mayhoub AS, Farag AM. Recent advances in the therapeutic applications of pyrazolines. Expert Opin. Ther. Patents 22, 253-291 (2012).

[15] Matiadis D, Sagnou M. Pyrazoline hybrids as promising anticancer agents: an up-todate overview. International Journal of Molecular Sciences 21 (15), 5507 (2020).

[16] Gul HI, Yamali C, Sakagami H et al. New anticancer druge candidates sulfonamides as selective hCA IX or hCA XII inhibitors. Bioorg. Chem. 77, 411-419 (2018).

[17] Zhang YL, Li BY, Yang R et al. A class of novel tubulin polymerization inhibitors exert effective anti-tumor activity via mitotic catastrophe. Eur. J. Med. Chem. 163, 896-910 (2019).

[18] Rathish IG, Javed K, Ahmad S et al. Synthesis and antiinflammatory activity of some new 1,3,5-trisubstituted pyrazolines bearing benzene sulfonamide. Bioorg. Med. Chem. Lett. 19, 255-258 (2009).

[19] Bansal E, Srivastava VK, Kumar A. Synthesis and anti-inflammatory activity of 1acetyl-5-substitute daryl-3-( $\beta$-aminonaphthyl)-2-pyrazolines and $\beta$-(substituted aminoethyl) amidonaphthalenes, Eur. J. Med. Chem. 36, 81-92 (2001).

[20] Shahar Yar M, Afroz Bakht M, Siddiqui AA, Abdullah MM, de Clercq E. Synthesis and evaluation in vitro antiviral activity of novel phenoxy acetic acid derivatives. $J$. Enzyme Inhib. Med. Chem. 24, 876-882 (2009).

[21] Özdemir Z, Kandilci HB, Gümüşel B, Çaliş Ü, Bilgin AA. Synthesis and studies on antidepressant and anticonvulsant activities of some 3-(2-furyl)-pyrazoline derivatives. Eur. J. Med. Chem. 42(3), 373-379 (2007). 
[22] Seebacher W, Michl G, Belaj F, Brun R, Saf R, Weis R. One-pot syntheses of 2pyrazolines derivatives. Tetrahedron 59, 2811-2819 (2003).

[23] Seebacher W, Belaj F, Saf R, Brun R, Weis R. New 1,3-thiazoles and 1,3-thiazines from 1-thiocarbamoylpyrazoles. Monatsch. Chem. 134, 1623-1628 (2003).

[24] Du X, Guo C, Hansell E et al. Synthesis and structure-activity relationship study of potent trypanocidal thio semicarbazone inhibitors of the trypanosomal cysteine protease cruzain. J. Med. Chem. 45, 2695-2707 (2002).

[25] Insuasty B, Ramírez J, Becerra D et al. An efficient synthesis of new caffeine-based chalcones, pyrazolines and pyrazolo[3,4-b][1,4]diazepines as potential antimalarial, antitrypanosomal and antileishmanial agents. Eur. J. Med. Chem. 93, 401-413 (2015).

[26] Cuartas V, Robledo SM, Vélez ID et al. New thiazolyl-pyrazoline derivatives bearing nitrogen mustard as potential antimicrobial and antiprotozoal agents. Arch. Pharm. 353, e1900351 (2020).

[27] Matiadis D, Karagiaouri M, Mavroidi B et al. Synthesis and antimicrobial evaluation of a pyrazoline-pyridine silver(I) complex: DNA-interaction and anti-biofilm activity. Biometals under review (2020).

[28] Baumstark AL, Dotrong M, Vasquez PC. Oxygen-atom transfer reagent: new, reactive $\alpha$-azohydroperoxides. Tetrahedron Lett. 28(18), 1963-1966 (1987).

[29] Cox CD, Breslin MJ, Mariano BJ. Two-step synthesis of $\beta$-alkyl chalcones and their use in the synthesis of 3,5-diaryl-5-alkyl-4,5-dihydropyrazoles. Tetrahedron Lett. 45, 1489-1493 (2004).

[30] Ciupa A, De Bank PA, Mahon MF, Wood PJ, Caggiano L. Synthesis and antiproliferative activity of some 3-(pyrid-2-yl)-pyrazolines. Med. Chem. Commun. 4, 956-961 (2013).

[31] Baumstark AL, Vasquez PC, McTush-Camp D. Synthesis and chemistry of structurally unique hexasubstituted pyrazolines. Heterocycl. Commun. 19(1), 13-17 (2013).

[32] Matiadis D, Mavroidi B, Panagiotopoulou A et al. (E)-(1-(4-Ethoxycarbonylphenyl)5-(3,4-dimethoxyphenyl)-3-(3,4-dimethoxystyryl)-2-pyrazoline: synthesis, characterization, DNA-interaction, and evaluation of activity against drug-resistant cell lines. Molbank 2020, M1114 (2020).

[33] Matiadis D, Papadakis R, Nowak K et al. Synthesis and (fluoro)solvatochromism of two 3-styryl-2-pyrazoline derivatives bearing benzoic acid moiety: A spectral, crystallographic and computational study. J. Mol. Liq. Under Review (2020).

[34] Sagnou M, Novikov FN, Ivanova ES et al. Novel curcumin derivatives as Pglycoprotein inhibitors: molecular modelling, synthesis and sensitization of multidrug resistant cells to doxorubicin. Eur. J. Med. Chem. 198, 112331 (2020). 
[35] Kolotova ES, Shtil AA, Novikov FN et al. Novel derivatives of 3,5-divinyl-pyrazole for medical application. WO2016/190770 A1, 01 December 2016.

[36] Álvarez G, Varela J, Márquez P, et al. Optimization of antitrypanosomatid agents: identification of nonmutagenic drug candidates with in vivo activity. J. Med. Chem. 57(10), 3984-3999 (2014).

[37] Klimova EI, Martinez GM, Klimova BT et al. Ene reactions of arylmethylenedihydropyrazoles with 4-phenyl-3h-1,2,4-triazole-3,5(4h)-dione. Synthesis 13, 1891-1897 (2002).

[38] Nuriev VN, Vatsadze IA, Sviridenkova NV, Vatsadze SZ. Synthesis of 3,7disubstituted hexahydro- and tetrahydro- $2 h$-indazoles from cross-conjugated dienones. Russ. J. Org. Chem. 52(3), 389-396 (2016).

[39] Lam KW, Tham CL, Liew CY et al. Synthesis and evaluation of DPPH and antiinflammatory activities of 2,6-bisbenzylidenecyclohexanone and pyrazoline derivatives. Med. Chem. Res. 21, 333-344 (2012).

[40] Bayomi SM, El-Kashef HA, El-Ashmawy MB et al. Synthesis and biological evaluation of new curcumin derivatives as antioxidant and antitumor agents. Med. Chem. Res. 22, 1147-1162 (2013).

[41] Minini L, Álvarez G, González M, Cerecetto H, Merlino A. Molecular docking and molecular dynamics simulation studies of Trypanosoma cruzi triosephosphate isomerase inhibitors. Insights into the inhibition mechanism and selectivity. J. Mol. Graph. Model. 58, 40-49 (2015).

[42] U.S. EPA (2016). "User's Guide for T.E.S.T. (version 4.2) (Toxicity Estimation Software Tool): A Program to Estimate Toxicity from Molecular Structure." Sushko I, Novotarskyi S, Körner R et al. Applicability domains for classification problems: benchmarking of distance to models for AMES mutagenicity set. J. Chem. Inf. Model. 50, 2094-2111 (2010).

[43] Daina A, Michielin O, Zoete V. SwissADME: A free web tool to evaluate pharmacokinetics, drug-likeness and medicinal chemistry friendliness of small molecules. Sci. Rep. 7, 42717 (2017). 